\title{
Multilevel Analysis of the Biopsychosocial Determinants and Contextual Peer Groups on Smoking Habit in High School Students in East Lampung, Lampung, Indonesia
}

\author{
Retno Sulistyani'), Setyo Sri Rahardjo²), Pawito3) \\ ${ }^{1)}$ Masters Program in Public Health, Universitas Sebelas Maret \\ 2) Faculty of Medicine, Universitas Sebelas Maret \\ 3)Faculty of Social and Political Sciences, Universitas Sebelas Maret
}

\section{ABSTRACT}

Background: Smoking is still one of the greatest public health threats faced by citizens of the world. Data from the Central Statistics Agency in 2018 shows that smoking behavior in Lampung Province has a prevalence of 35.95\%. The World Health Organization (WHO) states that smoking kills more than 8 million people per year worldwide. This study aimed to analyze the determinants of adolescent smoking behavior at the individual level and at the school level.

Subjects and Method: This was a cross sectional study conducted in East Lampung Regency, Indonesia, from October to November 2020. A number of 200 male adolescents were selected by random sampling. The dependent variable was smoking behavior. The independent variables were the influence of parents, peers, media exposure, pocket money, cigarette price, intention, attitude, and contextual effect of school. The data were collected by questionnaire and analyzed using a multiple multilevel logistic regression with Stata 13.

Results: The influence of family $(b=2.88 ; 95 \%$ $\mathrm{CI}=0.73$ to $3.85 ; \mathrm{p}=0.004)$, peers $(\mathrm{b}=2.85$; $95 \% \mathrm{CI}=0.65$ to $3.52 ; \mathrm{p}=0.004)$, media expo- sure $(b=3.04 ; 95 \% \mathrm{CI}=0.78$ to $3.62 ; \mathrm{p}=$ 0.002), money pocket $(\mathrm{b}=3.22 ; 95 \% \mathrm{CI}=0.87$ to $3.59 ; \mathrm{p}=0.001)$, cigarette price $(\mathrm{b}=2.73$; $95 \% \mathrm{CI}=0.54$ to $3.28 ; \mathrm{p}=0.006$ ), intention to smoke $(\mathrm{b}=2.80 ; 95 \% \mathrm{CI}=0.69$ to $3.95 ; \mathrm{p}=$ o.005), attitude toward smoking ( $b=3.83 ; 95 \%$ $\mathrm{CI}=1.80$ to $5.58 ; \mathrm{p}<0.001)$ increased the likelihood to smoke in male adolescents. School had strong contextual effect on smoking in adolescents with $\mathrm{ICC}=21.83 \%$.

Conclusion: The influence of family, peers, media exposure, money pocket, cigarette price, intention to smoke, attitude toward smoking increase the likelihood to smoke in male adolescents. School has strong contextual effect on smoking in adolescents

Keywords: smoking behavior, adolescents, contextual effect of school

\section{Correspondence:}

Retno Sulistiani. Masters Program in Public Health, Universitas Sebelas Maret. Jl. Ir. Sutami 36A, Surakarta 57126, Central Java. Email: retnosulistiani91@gmail.com. Mobile: +6285867006699 .

Cite this as:

Sulistyani R, Rahardjo SS, Pawito (2021). Multilevel Analysis of the Biopsychosocial Determinants and Contextual Peer Groups on Smoking Habit in High School Students in East Lampung, Lampung, Indonesia. J Health Promote Behav. 06(o1): 9-20. https://doi.org/10.26911/thejhpb.2021.06.01.02.

(c) () 5 () Journal of Health Promotion and Behavioris licensed under a Creative Commons Journal of Health Promotion and Behavioris licensed under a Creativ
Attribution-NonCommercial-ShareAlike 4.0 International License.

\section{BACKGROUND}

Smoking is still one of the biggest public health threats faced. The World Health Organization (WHO) states that smoking kills more than 8 million people per year worldwide (WHO, 2015). In 2015, it is estimated that there are more than one billion people smoking. About $80 \%$ of the world's smokers live in developing countries, namely low-income and middleincome countries (Alsubaie, 2018). 
The results of Riskesdas 2018 show that the prevalence of smoking at the age of 10-18 years shows an increase in 2016 as much as $8.8 \%$ and in 2018 as much as $9.1 \%$. In the age group over 15 years, the number of smokers was $33.8 \%$. Of these, $62.9 \%$ were male smokers and $4.8 \%$ were female smokers. This increase in the number of smokers is accompanied by an increase in the proportion of diseases caused by cigarette consumption such as hypertension, stroke, diabetes, heart disease, cancer (Ministry of Health, 2018). The results of data from the Central Statistics Agency in 2018 smoking behavior in Lampung Province has a prevalence of $35.95 \%$ (BPS, 2018).

Adolescents are very vulnerable to smoking behavior because it is considered as a means to help with physical, cognitive, and emotional changes that occur during this phase of life (Duncan et al, 2017). According to them, smoking among adolescents is a symbol of association, because if a group of adolescents has smoked then the individual adolescents in that group feel they must smoke because they do not want to be considered a stranger, not because the individual likes cigarettes (Isa et al, 2017) .

One of the factors influencing smoking behavior in adolescents is family and peers. Family is the primary unit which functions to transfer social and cultural factors, while friends are the source of identity formation in adolescents. The first experience of smoking in adolescents occurs when there are two social sub-agents at play, namely family and friends. Parents who smoke are not only role models but also increase adolescent access to cigarettes (Liem, 2014). Media exposure factors also affect smoking behavior in adolescents. The influence of media exposure is very influential on the lives of adolescents. When adolescents see advertisements on televi- sion and mass media, they begin to recognize and try to smoke (Ariani, 2011).

Smoking is one of the main risk factors for non-communicable diseases such as cardiovascular disease, stroke, chronic obstructive pulmonary disease, lung cancer, oral cancer, and abnormalities in pregnancy. These diseases are the main causes of death in the world (Kusumasari, 2017). Nearly $80 \%$ of smokers start smoking when they are not yet 19 years old. Generally, people start smoking at a young age and do not know the dangers of smoking addiction. The consumer's decision to buy cigarettes is not based on sufficient information about the risks of the purchased product, the effects of addiction and the impact of the purchase that is imposed on other people (Kemenkes RI, 2015).

This study aimed to analyze the determinants of adolescent smoking behavior at the individual level and at the school level.

\section{SUBJECTS AND METHOD}

\section{Study Design}

This was a cross sectional study conducted at 25 schools in East Lampung Regency, Indonesia, from October to November 2020.

\section{Population and Sample}

The population studied was all male adolescents in East Lampung Regency, from October to November 2020. Sampling was carried out using random sampling technique to select adolescents and schools in the East Lampung Regency. The subjects used were 200 subjects from 8 subjects in each level 2 (school).

\section{Study Variables}

The dependent variable was smoking behavior in adolescents. Independent variables were the influence of parents, peers, media exposure, pocket money, cigarette prices, intention, and attitude and level 2 is school. 
4. Operational Definition of Variables Smoking behavior is an activity or activity of smoking teenagers. The influence of parents is the attitude of adolescents towards the behavior of parents who smoke/ don't smoke at home.

Peers are peers as individual interactions in adolescents with the same age level and involve relative intimacy.

Media exposure is the exposure of adolescents through various kinds of mass media and electronic media related to cigarette advertisements/promotions both read, heard and seen by respondents. Pocket money is money that comes from giving from parents or other family members to meet the needs of teenagers in school.

The price of cigarettes is the price that must be paid to obtain cigarettes.

Intention is the desire made by adolescents to choose to participate or not in smoking behavior.

Attitudes are adolescent responses in the form of positive or negative assessments related to things that affect adolescents in smoking behavior. The scale of measurement in the independent variable is a continous scale, because for the needs of data analysis, it is converted into a dichotomous scale.

\section{Instruments}

The data is in the form of primary data and secondary data. Primary data were obtained using a questionnaire filled out by research subjects. Secondary data were obtained from the East Lampung District Health Office in the form of adolescent data in East Lampung Regency. The instrument used was a questionnaire.

\section{Data Analysis}

Univariate analysis was carried out to see the frequency distribution and characteristics of the research subjects, while bivariate analysis was performed using the chisquare test and the calculation of the odds ratio (OR) with a $95 \%$ confidence level (CI) to study the relationship between smoking behavior in adolescents and the independent variable. Multivariate analysis was carried out using logistic regression through a multilevel approach indicated by the Intra Class Correlation (ICC) value.

\section{Research Ethics}

Research ethics includes informed consent, anonymity, confidentiality and ethical clearance. The ethical clearance in this study was conducted at Dr. Moewardi Hospital, Surakarta and was declared ethical based on decree number: $1.188 / \mathrm{X} / \mathrm{HREC} /$ 2020.

\section{RESULTS}

\section{Univariate Analysis}

The univariate analysis included smoking behavior, family influence, peer influence, media exposure, pocket money, cigarette price, intention, and attitude.

Table 1. Univariate analysis (continuous data) influence of family, peer influence, media exposure, pocket money, cigarette price, intention, and attitude towards smoking behavior in adolescents.

\begin{tabular}{lccccc}
\hline \multicolumn{1}{c}{ Independent Variable } & N & Mean & SD & Min. & Max. \\
\hline Family influence & 200 & 5.40 & 1.07 & 2 & 7 \\
Peer influence & 200 & 5.40 & 1.17 & 1 & 7 \\
Media exposure & 200 & 3.76 & 0.87 & 0 & 5 \\
Pocket money & 200 & 411,250 & $95,952.97$ & 150,000 & 800,000 \\
Price of cigarettes & 200 & $11,762.50$ & $2,780.91$ & 8,000 & 20,000 \\
Intention & 200 & 2.83 & 0.88 & 0 & 4 \\
Attitude & 200 & 11.61 & 2.11 & 4 & 17 \\
\hline
\end{tabular}


Table 1 shows mean of family influence was $5.40($ Mean $=5.40 ; \mathrm{SD}=1.07)$. The mean of peer influence was 5.40 $($ Mean $=5.4 ; \mathrm{SD}=1.17)$. The mean of media exposure was 3.76 (Mean $=3.76$; $\mathrm{SD}=0.87)$. The allowance variable has a mean $=\mathrm{Rp} 411,250$ and $\mathrm{SD}=\mathrm{Rp}$.
95,952.97 with the lowest allowance $=\mathrm{Rp}$. 150,000 and the highest is Rp. 800,000. The mean of cigarette price was Rp 11,762 (Mean=11,762.50; $\mathrm{SD}=2,780.91)$. The mean of intention was 2.83 (Mean= 2.83; $\mathrm{SD}=0.88)$. The mean of attitude was $11.61($ Mean= 11.61; $\mathrm{SD}=2.11)$.

Table 2. Univariate analysis (dichotomous data) of family influence, peer influence, media exposure, pocket money, cigarette price, intention, and attitude towards smoking behavior in adolescents.

\begin{tabular}{lcc}
\hline \multicolumn{1}{c}{ Variable } & N & \% \\
\hline Smoking Behavior & 42 & \\
Smoke & 158 & 21.0 \\
Do not smoke & & 79.0 \\
Family Influence & 156 & 78.0 \\
Weak & 44 & 22.0 \\
Strong & & 78.0 \\
Peer Influence & 156 & 22.0 \\
Weak & 44 & 73.5 \\
Strong & 147 & 26.5 \\
Media Exposure & 53 & \\
Low & & 74.5 \\
High & 149 & 25.5 \\
Pocket money & 51 & \\
<450,ooo.oo & & 27.0 \\
Z450,ooo.oo & 54 & 73.0 \\
Cheap & 146 & 71.5 \\
Expensive & & 28.5 \\
Intention & 143 & 84.5 \\
Low & 57 & 15.5 \\
High & & \\
Attitude & & \\
Negative & & \\
Positive & 169 & \\
\hline
\end{tabular}

Table 2 shows that most of the study subjects who did not smoke were 158 (79.0\%), the influence of weak families was 157 study subjects (78.0\%), the influence of weak peers was 156 study subjects (78.0\%), low media exposure was 147 (73.5\%), pocket money $<\operatorname{Rp} 450,000$ as many as 149 (74.5\%), 146 (73.0\%) expensive cigarettes,
143 (71.5\%) low intention, and 169 (84.5\%) had positive attitude.

\section{Bivariate Analysis}

The statistical analysis used to see the effect of a dependent variable (smoking behavior) on the independent variable (family influence, peer influence, media exposure, pocket money, cigarette prices, intention, and attitude) is in table 5 . 
Table 3. Bivariate analysis of family influence, peer influence, media exposure, pocket money, cigarette prices, intention, and attitude towards smoking behavior in adolescents.

\begin{tabular}{|c|c|c|c|c|c|c|}
\hline \multirow{3}{*}{ Variable Group } & \multicolumn{4}{|c|}{ Smoking Behaviour } & \multirow{3}{*}{ OR } & \multirow{3}{*}{$\mathbf{p}$} \\
\hline & \multicolumn{2}{|c|}{ Yes } & \multicolumn{2}{|c|}{ No } & & \\
\hline & $\mathbf{n}$ & $\%$ & $\mathbf{n}$ & $\%$ & & \\
\hline Family Influence & & & & & 3.80 & $<0.001$ \\
\hline Weak & 24 & 46.1 & 132 & 83.5 & & \\
\hline Strong & 28 & 53.9 & 26 & 16.5 & & \\
\hline Peer Influence & & & & & 4.39 & $<0.001$ \\
\hline Weak & 23 & 54.7 & 133 & 84.1 & & \\
\hline Strong & 19 & $45 \cdot 3$ & 25 & 15.9 & & \\
\hline Media Exposure & & & & & 4.50 & $<0.001$ \\
\hline Low & 20 & 47.6 & 127 & 80.3 & & \\
\hline High & 22 & 52.4 & 31 & 19.7 & & \\
\hline Pocket money & & & & & 4.26 & $<0.001$ \\
\hline$<450,000.00$ & 21 & 50.0 & 128 & 81.0 & & \\
\hline$\geq 450,000.00$ & 21 & 50.0 & 30 & 19.0 & & \\
\hline Cigarette prices & & & & & 5.68 & $<0.001$ \\
\hline Cheap & 24 & 57.1 & 30 & 19.0 & & \\
\hline Expensive & 18 & 42.9 & 128 & 81.0 & & \\
\hline Intention & & & & & 3.86 & $<0.001$ \\
\hline Low & 20 & 47.6 & 123 & 77.8 & & \\
\hline High & 22 & 52.4 & 35 & 22.2 & & \\
\hline Attitude & & & & & 6.99 & $<0.001$ \\
\hline Negative & 25 & 59.5 & 144 & 91.1 & & \\
\hline Positive & 17 & 40.5 & 14 & 8.9 & & \\
\hline
\end{tabular}

Table 3 shows the results of the chisquare test of the influence of family, peer influence, media exposure, pocket money, cigarette prices, intention, and attitudes towards smoking behavior in adolescents as follows:

\section{a. The effect of family on smoking} behavior in adolescents

Weak family influence reduces the likelihood of smoking behavior in adolescents. Adolescents with weak family influence decreased the likelihood of smoking 3.80 times than adolescents with strong family influence $(\mathrm{OR}=3.80, \mathrm{p}<0.001)$.

\section{b. The effect of peers on smoking behavior in adolescents}

Weak peer influence reduces the likelihood of smoking behavior in adolescents. Adolescents with weak peer influence decreased the likelihood of smoking 4.39 times than adolescents with strong peer influence (OR=4.39, $\mathrm{p}<0.001)$.

c. The effect of media exposure on smoking behavior in adolescents

Low media exposure decreases the likelihood of smoking behavior in adolescents. Adolescents with low media exposure decreased the likelihood of smoking 4.50 times than adolescents with high media exposure (OR $=4.50, \mathrm{p}<0.001)$.

d. The effect of pocket money on smoking behavior in adolescents

Adolescents with an allowance of $<\mathrm{Rp}$ 450,000 reduce the likelihood of smoking behavior in adolescents. Adolescents with an allowance of $<R p 450,000$ reduce the likelihood of smoking 4.26 times than adolescents with an allowance of $\geq R p 450,000$ $(\mathrm{OR}=4.26, \mathrm{p}<0.001)$. 
e. The effect of cigarette price on smoking behavior in adolescents

The high price of cigarettes reduces the likelihood of smoking behavior among adolescents. Adolescents who thought the price of cigarettes was expensive decreased the likelihood of smoking 5.68 times $(\mathrm{OR}=$ $5.68, \mathrm{p}<0.001)$.

\section{f. The effect of intention on smoking} behavior in adolescents

Adolescents with weak intention reduce the likelihood of smoking behavior in adolescents. Adolescents with weak intention decreased the likelihood of smoking 3.86 times $(\mathrm{OR}=3.86, \mathrm{p}<0.001)$.

Table 4. The results of multilevel multiple logistic regression analysis of the effect of family, peer, media exposure, pocket money, cigarette price, intention, and attitude on smoking behavior in adolescents

\begin{tabular}{|c|c|c|c|c|}
\hline \multirow{2}{*}{ Independent Variable } & \multirow{2}{*}{ b } & \multicolumn{2}{|c|}{$95 \% \mathrm{CI}$} & \multirow[b]{2}{*}{$\mathbf{p}$} \\
\hline & & Lower Limit & Upper Limit & \\
\hline \multicolumn{5}{|l|}{ Fixed Effect } \\
\hline Family influence (strong) & 2.88 & 0.73 & 3.85 & 0.004 \\
\hline Peer influence (strong) & 2.85 & 0.65 & 3.52 & 0.004 \\
\hline Media exposure (high) & 3.04 & 0.78 & 3.62 & 0.002 \\
\hline Allowance ( $\geq$ Rp.450,00o.oo) & 3.22 & 0.87 & 3.59 & 0.001 \\
\hline Price of cigarettes (cheap) & 2.73 & 0.54 & 3.28 & 0.006 \\
\hline Intention (high) & 2.80 & 0.69 & 3.95 & 0.005 \\
\hline Attitude (positive) & 3.83 & 1.80 & 5.58 & 0.000 \\
\hline \multicolumn{5}{|l|}{ Random effect } \\
\hline Schools & 0.91 & & & \\
\hline $\mathrm{N}$ observation $=200$ & & & & \\
\hline $\mathrm{N}$ group $=25$ & & & & \\
\hline Average of group $=8, \min =8, \max =8$ & & & & \\
\hline Log likelihood $=-49.05$ & & & & \\
\hline$p=0.003$ & & & & \\
\hline p LR test vs logistic regression $=0.132$ & & & & \\
\hline $\mathrm{ICC}=21.83 \%$ & & & & \\
\hline
\end{tabular}

Table 4 shows the results of a multilevel analysis of smoking behavior in adolescents using a multiple multilevel logistic regression. The results of the analysis can be described as follows:

\section{a. The effect of family on smoking behavior in adolescents}

There is a positive influence between the influence of family on smoking behavior in

\section{g. The effect of attitude on smoking behavior in adolescents}

Teens with a positive attitude reduce the likelihood of smoking behavior in adolescents. Adolescents with positive attitude decreased the likelihood of smoking 6.99 times $(\mathrm{OR}=6.99, \mathrm{p}<0.001)$.

\section{Multivariate Analysis}

Multilevel multiple logistic regression analysis explains the effect of more than one independent variable and variable at level 2 , namely school. The results of the analysis can be seen in Table 4 . adolescents. Adolescents with strong family influence had a risk (logodd) for smoking 2.88 units higher than adolescents with weak family influence $(b=2.88 ; 95 \% \mathrm{CI}=$ 0.73 to $3.85 ; \mathrm{p}=0.004$ ).

b. The effect of peers on smoking behavior in adolescents

There is a positive influence between peer influence on smoking behavior in adoles- 
cents. Adolescents with strong peer influence had a risk (logodd) of smoking 2.85 units higher than adolescents with weak peer influence $(b=2.85 ; 95 \% \mathrm{CI}=0.65$ to $3.52 ; \mathrm{p}=0.004)$.

c. The effect of media exposure on smoking behavior in adolescents

There is a positive influence between media exposure on smoking behavior in adolescents. Adolescents who had high media exposure had a risk (logodd) of smoking 3.04 units higher than adolescents who had low media exposure $(b=3.04 ; 95 \% \mathrm{CI}=$ 0.78 to $3.62 ; \mathrm{p}=0.002)$.

d. The effect of pocket money on smoking behavior in adolescents

There is a positive influence between pocket money on smoking behavior in adolescents. Adolescents with an allowance of $\geq \mathrm{Rp}$ 450,000 have a risk (logodd) of smoking 3.22 units higher than adolescents who have an allowance of $<\operatorname{Rp} 450,000(b=$ $3.22 ; 95 \% \mathrm{CI}=0.87$ to $3.59 ; \mathrm{p}=0.001$ ).

e. The effect of cigarette prices on smoking behavior in adolescents

There is a positive influence between the price of cigarettes on smoking behavior in adolescents. Adolescents who thought the price of cigarettes was cheap had a risk (logodd) to smoke 2.73 units higher than adolescents who thought the price of cigarettes was expensive $(b=2.73 ; 95 \% \mathrm{CI}=$ 0.54 to $3.28 ; \mathrm{p}=0.006$ ).

\section{f. The effect of intention on smoking behavior in adolescents}

There is a positive influence between intention on smoking behavior in adolescents. Adolescents who had high intention had a risk (logodd) to smoke 2.80 units higher than adolescents who had low intention $(b=$ $2.80 ; 95 \% \mathrm{CI}=0.69$ to $3.95 ; \mathrm{p}=0.005$ ).

g. The effect of attitudes on smoking behavior in adolescents

There is a positive influence between attitude on smoking behavior in adolescents.
Adolescents who had a positive attitude towards smoking had a risk (logodd) for smoking 3.83 units higher than adolescents who had negative attitudes towards smoking $(b=3.83 ; 95 \% \mathrm{CI}=1.80$ to 5.58 ; $\mathrm{p}<0.001)$.

h. The effect of school on smoking behavior in adolescents

The school level shows that there is a contextual influence on smoking behavior in adolescents $(\mathrm{ICC}=21.83 \%)$. The variation of smoking behavior among adolescents was $21.83 \%$ influenced by school. Table 4.4 shows that the ICC score in this study is greater than the $8-10 \%$ rule of thumb, so the contextual influence in this study is that school is very important to note.

\section{DISCUSSION}

1. The influence of family on smoking behavior in adolescents

Family has an important influence on the behavior that occurs in adolescents. One of them is smoking behavior. In a family, if one member of the family smokes, it is likely that it will influence them or other family members to smoke, especially children, they smoke to show their identity so that they can look more mature like their father or siblings who others (Roupa et al., 2016; Mcgee et al., 2015).

The family environment has an important role in preventing or promoting smoking, especially parents have a very important role in the process of developing children's behavior. Children will imitate good behavior from their parents. In the form of good behavior and bad behavior. Like the smoking habit of parents and other family members (Mulvhill, 2014; Soesyasmoro et al., 2016; Alves et al., 2016).

\section{The influence of peers on smoking behavior in adolescents}

Peers can also positively influence smoking behavior through the same mechanisms of 
peer influence and selection. Peers give influence to continue smoking. This is because gathering with peers is a habit and has become a lifestyle for adolescents so that adolescents want to share in the taste of cigarettes or because they have bad feelings for friends who smoke (Mulvhill, 2014; Pandayu et al., 2017; Arifiyanti et al., 2019).

Atmojo et al. (2017) show that peers have an influence on smoking behavior in adolescents. Adolescents have a perspective on smoking behavior that is greatly influenced by their peers. Perspectives will determine the decision taken in the end whether a teenager will smoke or not. The behavior of popular friends is stronger than the influence of unpopular friends. The smoking tendency of $80 \%$ of their most popular friends has a negative long-term effect on individual smokers. The popularity of a friend influences the influence of friends on various risky behaviors, such as smoking behavior, binge drinking, drug abuse, and sexual behavior (Robalino and Macy, 2018; Amorha et al., 2017; Panduwinata et al., 2018; Atmojo et al. , 2017).

\section{The influence of media exposure on smoking behavior in adoles- cents}

This is in line with the research of Mangunsong et al., (2016) which states that cigarette advertisements that describe the dangers of smoking can explain smoking behavior by $16.2 \%$. The existence of modern media has created an establishment that can lead to a causal relationship between media and smoking. The cigarette industry is rapidly adopting television as its main advertising medium, and consumers are well aware of the cigarette brands being promoted on television. Cigarette companies have hired micro-influencers to promote them and they smoke in general. This can influence someone who sees advertise- ments or micro-influencers to imitate their behavior (Thomas, 2016).

Media exposure has a positive correlation with the perception of smoking prevalence, which in turn has a positive correlation with smoking intention. This overview of smoking increases adolescent perceptions of smoking prevalence. If adolescents perceive smoking as normative behavior, they may consider the behavior permissible and intend to adopt the behavior. However, if the image of the smoker is not good in the media, it can reduce the effect of the perception of smoking behavior. Social media serves as an effective communication channel to generate, share, receive, and comment on content about smoking (Yang et al., 2013; Yoo et al., 2016).

\section{The effect of pocket money on smoking behavior in adolescents}

This is in line with Arifiyanti et al. (2019) which states that adolescents with an allowance of $>$ Rp 300,000 per month increase smoking behavior by 2.89 units compared to adolescents with an allowance of $\leq \mathrm{Rp}$ 300,000 per month. Tobacco use was found more in adolescents who earned high allowances. This is also in accordance with the results of research which shows the same relationship, namely adolescents who have a high amount of pocket money tend to support the behavior of using their pocket money to buy cigarettes, the higher the allowance owned by adolescents, the more likely the teenager to buy cigarettes (Anggarwal and Kumar, 2014).

Purnaningrum et al., (2017) also shows a significant relationship between pocket money and smoking behavior in adolescents. The availability of high pocket money will affect the increase in smoking behavior among adolescents. Allowance should be given on a policy basis and not excessive. Allowance given unwise will cause problems, namely adolescents 
become extravagant, adolescents do not value money and teenagers are lazy to learn, so that teenagers tend to be tempted and feel addicted to spending pocket money by buying cigarettes because the price of cigarettes is not expensive and they can buy sticks Pandayu et al., 2017).

\section{The effect of cigarette prices on smoking behavior in adolescents}

Arifiyanti et al., (2019) shows that adolescents with perceptions of cheap cigarette prices are likely to increase smoking behavior by 2.84 units compared to adolescents with perceptions of expensive cigarette prices. Smoking behavior usually occurs during adolescence. The link between price cigarettes and tobacco use is very strong among young people. Smokers are more sensitive to price. Efforts to reduce cigarette purchases by increasing cigarette prices by $10 \%$ reduce a person to smoke by $11.3 \%$ (Cui et al., 2019).

\section{The effect of intention on smoking behavior in adolescents}

Smoking behavior is positively related to smoking intention. If adolescents perceive smoking as normative behavior, they may consider the behavior permissible and intend to adopt the smoking behavior. Someone who has a high intention to smoke, smoking behavior can occur (Yang et al., 2013; Riyadi et al., 2019).

The results of study by Delpia et al., (2016) show that subjective norms have an indirect positive effect through intention. Subjective norms contain beliefs about the social pressure that individuals get and feel from the expectations of people who have a high enough influence on their lives. The higher the expectations of other people who are considered important for their lives to prevent smoking behavior, the higher a person's intention to carry out preventive behavior.The higher a person's intention, the higher the likelihood of smoking behavior (Pandayu et al., 2017; Ganley and Rosario 2013).

\section{The influence of attitudes on} smoking behavior in adolescents

This study is in line with Riyadi et al., (2019) which states that attitudes have a direct relationship with smoking behavior with $\mathrm{p}=0.004$. Attitude is a person's tendency to respond, assess or express both beliefs, feelings or behavior towards an idea, event or situation that is socially important. Attitudes include situations in which individuals have ambivalent (ambivalent) assessments of an object, namely having positive or negative attitudes towards the same object (Murti, 2018).

The results of the study by Panduwinata et al., (2018) support the theory that attitude is a predictor of smoking behavior. Adolescents in general have a high curiosity attitude, because they are driven by high curiosity, adolescents tend to want to be adventurous to explore everything and try everything they have never experienced and are also driven by desire like adults causing teenagers to want to try to do what they often do. done by adults. As a result, it is not uncommon for boys to secretly try to smoke because they often see adults doing it (Ganley and Rosario 2013; Delpia et al., 2016; Pandayu et al., 2017)

\section{The influence of schools on smoking behavior in adolescents}

School is a place of education that can be said to be successful if it is able to change children's behavior for the better. At school it can also lead to behavior changes in adolescents, both positive behavior and negative behavior. One of the negative behaviors that can occur in school is smoking behavior in adolescents. Although in fact at school itself there are rules that prohibit smoking. But sometimes students smoke in school secretly. It is because at school they also meet their peers (Roupa et al., 2016). 
Sulistyani et al./ Biopsychosocial Determinants and Contextual Peer Groups on Smoking Habit

This is in line with Robalino and Macy (2018) which states that $20 \%$ of adolescents smoke at school. Schools with no education about smoking are more likely to be adolescents who smoke because of their lack of knowledge. School really determines adolescents to have more opportunities to interact with people of the opposite gender, teenagers in this school can use cigarettes to project an image of maturity. Teens tend to perceive smoking as a symbol of maturity or attractiveness (Heo et al., 2014).

AUTHOR CONTRIBUTION
Retno Sulistiani acted as the main
researcher who coordinated the research,
carried out all stages of the research, and
completed the research paper. Setyo Sri
Rahardjo played a role in compiling the
research framework, processing research
data, presenting the results of research
analysis, and preparing research papers.
Pawito plays a role in developing ideas,
research designs, and research hypotheses.

\section{CONFLICT OF INTEREST}

There is no conflict of interest in this study.

\section{FUNDING AND SPONSORSHIP}

This study is self-funded.

\section{ACKNOWLEDGEMENT}

Our gratitude goes to all school principals and high school teachers in the district of East Lampung who has helped research and students who have been willing to become research subjects.

\section{REFERENCE}

Aggarwal J, Kumar M (2014). Prevalence of microalbuminuria among rural North Indian population with diabetes mellitus and its correlation with glycosylated haemoglobin and smoking. J Clin Diagnostic Res. 8(7): 11-13. https://doi.org/10.786o/jcdr/2014/9 758.4613 .

Alsubaie ASR (2018). Prevalence and determinants of smoking behavior among male school adolescents in Saudi Arabia. Int $\mathrm{J}$ Adolesc Med Health. 32(4). https://doi:10.1515/ijamh-2017-0180.

Alves J, Perelman J, Soto-Rojas V, Richter M, Rimpela A, Loureiro I, Federico B, et al. (2016). The role of parental smoking on adolescent smoking and its social patterning: A cross-sectional survey in six European cities. Journal of Public Health. 39(2): 339-346. https://doi.org/10.1093/pubmed/fdw 040.

Amorha KC, Jiburu EM, Nduka SO, Okonta MJ (2017). Cigarette smoking prevalence and awareness amongst undergraduate students of the University of Nigeria, Nsukka. J Basic Clin Pharm. 8: 239-244. https://www.jbclinpharm.org/articles/cigarette-smoking-prevalence-and-awareness-amongst-undergraduate-students-of-the-university-of-nigeria-nsukka-3934.html.

Ariani RD. 2011. Hubungan antara iklan rokok dengan sikap dan perilaku merokok pada remaja (Studi kasus di SMAN Semarang). The relationship between cigarette advertising and smoking attitudes and behaviors in adolescents (Case Study at SMAN Semarang). Artikel ilmiah Semarang: Progam Studi Sarjana Kedokteran Fakultas Kedokteran Universitas Diponegoro.

Arifiyanti T, Soemato RB, Prasetya $\mathrm{H}$ (2019). The contextual effect of school on smoking behavior among male high school students. J Health Promot Behav. 4(1): 76-84. https://doi.org/10.26911/thejhpb.2019.04.01.08. 
Atmojo JT, Soemanto RB, Murti B (2017. Determinants of successful smoking cessation in Surakarta, Central Java. J Health Promot Behav. 2(4): 332-342. https://doi.org/10.26911/thejhpb.201 7.02.04.05.

Cui Y, Forget EL, Zhu Y, Torabi M, Oguzoglu U (2019). The effects of cigarette price and the amount of pocket money on youth smoking initiation and intensity in Canada. Canadian $\mathbf{J}$ Public Health. 110: 93-102. https://doi.org/10.17269/s41997-018-0123-9.

Delpia YV, Murti B, Suryani N (2016). Theory of planned behavior: Analysis of factors affecting the preventive behaviors of alcohol consumption and smoking among students from West Kalimantan, in Yogyakarta. J Health Promot Behavi. 1(2): 62-69. https://doi.org/10.26911/thejhpb.2016.01.02. 01.

Duncan LR, Pearson ES, Maddison R (2017). Smoking prevention in children and adolescents: a systematic review of individualized interventions. Patient Educ Couns. 101 (3): 375388. https://doi:10.1016/j.pec.2017.09.011.

Ganley BJ, Rosario DI (2013). The smoking attitudes, knowledge, intent, and behaviors of adolescents and young adults: Implications for nursing practice. Journal of Nursing Education and Practice. 3(1). http://dx.doi.org/10.5430/jnep.v3n1p40.

Heo J, Oh J, Subramanian S, Kawachi I (2014). Household and school-level influences on smoking behavior among Korean adolescents: A multilevel analysis. PLoS ONE. 9(6). https://doi.org/10.1371/journal.pone.0098 683.

Isa L, Lestari H, Afa JR (2017). Hubungan tipe kepribadian, peran orang tua dan saudara, peran teman sebaya, dan peran iklan rokok dengan perilaku merokok pada siswa SMP Negeri 9 Kendari tahun 2017 (The relationship of personality types, the roles of parents and siblings, the role of peers, and the role of cigarette advertising with smoking behavior in Junior High School 9 Kendari students in 2017). Jurnal Ilmiah Mahasiswa Kesehatan Masyarakat. 2(7): 2.

Kemenkes RI (2015). Infodatin: Perilaku merokok masyarakat Indonesia (Indonesian Community Smoking Behavior). Jakarta: Kemenkes RI. ISSN: 2442-7659.

Kemenkes RI (2018). Rokok: Akar masalah jantung dan melukai hati keluarga (Cigarettes: Roots of heart problems and heartbreaking families). Jakarta: Kemenkes RI.

Kusumasari R (2017). Rokok ancam kita dan pembangunan (Cigarettes threaten us and development). Jawa tengah: Dinas Kesehatan Jawa Tengah.

Liem A (2014). Influences of mass media, family, and friends towards adolescents' smoking in Yogyakarta. Makara Hubs-Asia, 18(1): 41-52. https://doi:10.7454/mssh.v18i1.3460.

Mangunsong RRD, Murti B, Wijaya M (2016). Association between cigarette package warning messages, self-efficacy, and smoking behavior among students at health polytechnic in Surakarta, Indonesia. J Health Policy Manage. 1(1): 44-52. https://doi.org/thejhpm.2016.01.01.07.

Mcgee CE, Trigwell J, Fairclough SJ, Murphy RC, Porcellato L, Ussher M, Foweather L (2015). Influence of family and friend smoking on intentions to smoke and smoking-related attitudes and refusal self-efficacy among 9-10 year old children from deprived 
Sulistyani et al./ Biopsychosocial Determinants and Contextual Peer Groups on Smoking Habit

neighbourhoods: A cross-sectional study. BMC Public Health. 15(225). https://doi10.1186/s12889-015-1513$\mathrm{z}$.

Mulvhill C (2014). Parental and peer influences on adolescent smoking: A literature review. Interdisciplinary $\mathrm{J}$ Health Sci. 4(1). https://doi.org/10.18192/riss-ijhs.v4i1.1218.

Murti B (2018). Teori promosi dan perilaku kesehatan. Edisi ke-satu (Promotion Theory and Health Behavior 1st Edition). Karanganyar: Bintang Fajar Offset.

Pandayu A, Murti B, Pawito (2017). Effect of personal factors, family support, pocket money, and peer group, on smoking behavior in adolescents in Surakarta, Central Java. J Health Promot Behavior. 2(2): 98-111. https://doi.org/10.26911/thejhpb.2017.02. 02.01.

Panduwinata AW, Murti B, Pawito (2018). Multilevel analysis of the effect of school and peer group on smoking behavior in adolescents in Banjarnegara. J Health Promot Behav. 3(3): 166-178. https://doi.org/10.26911/thejhpb.2018.03.03.04.

Purnaningrum WD, Joebagio H, Murti B (2017). Association between cigarette advertisement, peer group, parental education, family income, and pocket money with smoking behavior among adolescents in Karanganyar District, Central Java. J Health Promot Behav. 2(2): 150-16o. https://doi.org/10.26911/thejhpb.2016.02.02.05.

Riyadi S, Murti B, Akhyar M, Suminah (2019). Predicting tobacco smoking among adolescents using social capital and media exposure with Theory of
Planned Behavior: Path analysis evidence from Indonesia. Global $\mathrm{J}$ Health Sci. 11(7). https://doi.org/10.5539/gjhs.v11n7p18

Robalino JD, Macy M (2018). Peer effects on adolescent smoking: Are popular teens more influential?. PLOS ONE. 13(7). https://doi.org/10.1371/journal.pone.0189360.

Roupa Z, Vasilopoulos A, Hatzoglou C, Gourgoulianis K, Kefaliakos A, Mechili EA, Archangelidi O, Mentzakis E, Diomidous M (2016). The effect of family and social environment on smoking behaviour in adolescence. European Scientific Journal. 12(2). https://doi:10.19044/esj.2016.v12n2p 62.

Soesyasmoro RA, Demartoto A, Adriani RB (2016). Effect of knowledge, peer group, family, cigarette price, stipend, access to cigarette, and attitude, on smoking behavior. J Health Promot Behav. 1(3): 202-211. https://doi.org/10.26911/thejhpb.2016.01.03.07.

Thomas M (2016). Was television responsible for a new generation of smokers? Journal of Consumer Research. 46. https://doi:10.1093/jcr/uczo24.

Yang F, Salmon CT, Pang JP, Cheng WJY (2013). Media exposure and smoking intention in adolescents: A moderated mediation analysis from a cultivation perspective. SAGE. https://doi:10.1177/1359105313501533.

Yoo W, Yang J, Cho E (2016). How social media influence college students' smoking attitudes and intentions. Comput Human Behav. 64: 173-182. https://doi:10.1016/j.chb.2016.06.06 1. 